\title{
Article \\ A Systematic Study of Ammonia Recovery from Anaerobic Digestate Using Membrane-Based Separation
}

\author{
Fanny Rivera ${ }^{1,2}$, Raúl Muñoz ${ }^{1,3}$, Pedro Prádanos ${ }^{1,2} \mathbb{D}$, Antonio Hernández ${ }^{1,2}$ and Laura Palacio ${ }^{1,2, *(\mathbb{D})}$ \\ 1 Institute of Sustainable Processes, University of Valladolid, 47011 Valladolid, Spain; \\ fannymaritza.rivera@uva.es (F.R.); mutora@iq.uva.es (R.M.); ppradanos@uva.es (P.P.); \\ antonio.hernandez@uva.es (A.H.) \\ 2 Department of Applied Physics, Science Faculty, University of Valladolid, 47011 Valladolid, Spain \\ 3 Department of Chemical Engineering and Environmental Technology, University of Valladolid, \\ 47011 Valladolid, Spain \\ * Correspondence: laura.palacio@uva.es
}

check for updates

Citation: Rivera, F.; Muñoz, R.;

Prádanos, P.; Hernández, A.; Palacio, L. A Systematic Study of Ammonia Recovery from Anaerobic Digestate Using Membrane-Based Separation.

Membranes 2022, 12, 19.

https://doi.org/10.3390/

membranes12010019

Academic Editors: Heitor Bento and Cristiano E. Rodrigues Reis

Received: 9 December 2021

Accepted: 23 December 2021

Published: 24 December 2021

Publisher's Note: MDPI stays neutral with regard to jurisdictional claims in published maps and institutional affiliations.

Copyright: (c) 2021 by the authors. Licensee MDPI, Basel, Switzerland. This article is an open access article distributed under the terms and conditions of the Creative Commons Attribution (CC BY) license (https:/ / creativecommons.org/licenses/by/ $4.0 /)$.

\begin{abstract}
Ammonia recovery from synthetic and real anaerobic digestates was accomplished using hydrophobic flat sheet membranes operated with $\mathrm{H}_{2} \mathrm{SO}_{4}$ solutions to convert ammonia into ammonium sulphate. The influence of the membrane material, flow rate $(0.007,0.015,0.030$ and $\left.0.045 \mathrm{~m}^{3} \mathrm{~h}^{-1}\right)$ and $\mathrm{pH}(7.6,8.9,10$ and 11$)$ of the digestate on ammonia recovery was investigated. The process was carried out with a flat sheet configuration at a temperature of $35^{\circ} \mathrm{C}$ and with a $1 \mathrm{M}$, or $0.005 \mathrm{M}, \mathrm{H}_{2} \mathrm{SO}_{4}$ solution on the other side of the membrane. Polytetrafluoroethylene membranes with a nominal pore radius of $0.22 \mu \mathrm{m}$ provided ammonia recoveries from synthetic and real digestates of $84.6 \% \pm 1.0 \%$ and $71.6 \% \pm 0.3 \%$, respectively, for a membrane area of $8.6 \times 10^{-4} \mathrm{~m}^{2}$ and a reservoir volume of $0.5 \mathrm{~L}$, in $3.5 \mathrm{~h}$ with a $1 \mathrm{M} \mathrm{H}_{2} \mathrm{SO}_{4}$ solution and a recirculation flow on the feed side of the membrane of $0.030 \mathrm{~m}^{3} \mathrm{~h}^{-1}$. $\mathrm{NH}_{3}$ recovery followed first order kinetics and was faster at higher $\mathrm{pHs}$ of the $\mathrm{H}_{2} \mathrm{SO}_{4}$ solution and recirculation flow rate on the membrane feed side. Fouling resulted in changes in membrane surface morphology and pore size, which were confirmed by Atomic Force Microscopy and Air Displacement Porometry.
\end{abstract}

Keywords: ammonia recovery; anaerobic digestate; flat sheet membranes; mass transfer; membrane fouling

\section{Introduction}

A change in the perception of the uses of anaerobic digestion has occurred over past decades. Thus, anaerobic digestion was initially considered as a cost-competitive technology for organic matter stabilization in wastewaters and solid waste, then a sustainable platform for renewable electricity and heat generation via biogas production, and more recently, it has been regarded as the potential core of a multiproduct biorefinery. Energy and carbon in the form of biogas, along with nutrients dissolved in anaerobic effluents (typically called digestates), represent nowadays the main by-products from anaerobic waste treatment. $\mathrm{NH}_{3}$ recovery from digestates will prevent the pollution of natural water bodies, which is desirable as this nitrogenous compound is toxic to fish, increases oxygen demand and induces eutrophication [1]. $\mathrm{NH}_{3}$ is also harmful to humans as it causes respiratory problems and is considered a precursor of $\mathrm{N}_{2} \mathrm{O}$, a potent greenhouse gas [2-4]. Therefore, $\mathrm{NH}_{3}$ recovery from digestates is crucial to improve the environmental sustainability of anaerobic digestion processes and could bring additional economic benefits. Unfortunately, only $10 \%$ of the nitrogen present in wastewater is recovered by conventional wastewater treatment plants (WWTPs) [5-7]. Today, there is a wide range of commercial technologies to remove ammonia from wastewater, but most of them entail high operating costs [8] and environmental impacts resulting from nitrogen conversion and release to the atmosphere. Thus, conventional physical/chemical technologies are based on selective ion exchange, air stripping, chemical precipitation, adsorption, advanced oxidation processes, breakpoint 
chlorination, etc. [9-12]. For instance, $\mathrm{NH}_{3}$ stripping ranks among the most popular, but energy demanding, technologies available to remove nitrogen from high-strength wastewater, with an average energy consumption of $4 \mathrm{kwh}$ per $\mathrm{kg}$ of nitrogen [13]. On the other hand, conventional nitrogen removal in domestic WWTPs relies on nitrification, which is the conversion of ammoniacal nitrogen $\left(\mathrm{NH}_{3}-\mathrm{N}\right)$ to $\mathrm{NO}_{3}^{-}$, and denitrification, which is the conversion of $\mathrm{NO}_{3}^{-}$to $\mathrm{N}_{2}$ gas [14-16]. In this context, $1.5 \mathrm{kWh}$ of electricity are typically required to remove $1 \mathrm{~kg}$ of $\mathrm{N}$ in denitrification/nitrification or anammox processes [17]. In addition, conventional biological nitrogen removal in WWTPs entails $0.9 \mathrm{~kg} \mathrm{CO}_{2}$ eq per $\mathrm{m}^{3}$ of treated water $[18,19]$. Therefore, there is an urgent need to develop and implement cost-competitive and sustainable $\mathrm{NH}_{3}$ recovery technologies in high strength wastewater such as digestates [20-22].

Recently, the use of membranes for $\mathrm{NH}_{3}$ recovery from high strength wastewater has been proposed as a cost-competitive and environmentally friendly approach to upgrade residual nitrogen. For example, Brennan et al. [23] made an extensive analysis of costs demonstrating the feasibility of $\mathrm{NH}_{3}$ recovery by membranes over conventional methods at a pilot plant scale. Membrane contactors require less energy because of their high specific surface area, which provides a faster $\mathrm{NH}_{3}$ separation. In this context, membrane contactors have been successfully implemented for $\mathrm{NH}_{3}$ recovery from gaseous emissions [24-26]. Membrane contactors have also been implemented to support a direct $\mathrm{NH}_{3}$ recovery from wastewater [27-29]. This approach is based on hydrophobic membranes made of polymers highly permeable to $\mathrm{NH}_{3}$, which is transported through the membrane pores into the receiving liquid phase recirculating through the permeate side $[20,21,30]$. This permeating $\mathrm{NH}_{3}$ reacts with an acid contained in the permeate side of the membrane. For the process to be efficient, ammoniacal nitrogen has to be present in its volatile form $\left(\mathrm{NH}_{3}\right)$, which can be ensured by increasing $\mathrm{pH}$ and temperature [22]. Ammonium sulphate, a commercial chemical fertilizer, can be generated during membrane-based $\mathrm{NH}_{3}$ recovery when using $\mathrm{H}_{2} \mathrm{SO}_{4}$ to boost $\mathrm{NH}_{3}$ diffusion (Equation (1)) [31]. The use of $\mathrm{H}_{3} \mathrm{PO}_{4}$ and $\mathrm{HNO}_{3}$ on the permeate side also results in the generation of chemical fertilizers such as ammonium phosphate and ammonium nitrate, respectively [27-29]. In this regard, Damtie and coworkers concluded that $\mathrm{H}_{2} \mathrm{SO}_{4}$ mediates a more effective ammonia capture than $\mathrm{H}_{3} \mathrm{PO}_{4}$ and $\mathrm{HNO}_{3}$ [32].

$$
2 \mathrm{NH}_{3}+\mathrm{H}_{2} \mathrm{SO}_{4} \rightarrow\left(\mathrm{NH}_{4}\right)_{2} \mathrm{SO}_{4}
$$

In this work, the performance of commercial flat sheet membranes for $\mathrm{NH}_{3}$ recovery from synthetic and real digestates was systematically evaluated. To optimize the operation conditions, the influence of digestate $\mathrm{pH}$, within the range of coexisting $\mathrm{NH}_{4}{ }^{+}, \mathrm{NH}_{3}$ [33], and recirculation flow rate, was investigated using different concentrations of sulfuric acid on the other side of the membrane. To make this new ammonia process accessible, our proposal involves the use of commercial membranes that were previously employed for other applications. By scanning the variables that can be controlled at the place of installation, we reached the optimal conditions, without using the latest generation and non-commercial materials. Ultimately, our objective was to propose a solution within the reach of the farmer who intends to implement it in their facilities. Finally, membrane fouling was studied using Atomic Force Microscopy (AFM) to examine the surface morphology of the membranes and Air Displacement Porometry (ADP) to determine the corresponding changes of the pore sizes of the membranes.

\section{Materials and Methods}

\subsection{Real and Synthetic Digestate Characterization}

The synthetic digestate (SD) composition mimicked a real digestate and consisted of $5.0 \mathrm{~g} \mathrm{NaHCO}_{3}, 0.85 \mathrm{~g} \mathrm{C}_{8} \mathrm{H}_{5} \mathrm{KO}_{4}, 0.73 \mathrm{~g}$ peptone from casein, $1.70 \mathrm{~g} \mathrm{NH}_{4} \mathrm{Cl}, 0.90 \mathrm{~g}$ $\mathrm{CO}\left(\mathrm{NH}_{2}\right)_{2}, 0.224 \mathrm{~g} \mathrm{~K}_{2} \mathrm{HPO}_{4}, 0.0175 \mathrm{~g} \mathrm{NaCl}, 0.01 \mathrm{Ca}_{2} \mathrm{Cl}$ and $0.005 \mathrm{~g} \mathrm{MgSO}_{4}$ (per litre of distilled water) [34]. All reagents were purchased from PANREAC (Panreac, Química SAU, Barcelona, Spain). The real digestate (RD) used in this study was supplied by Valladolid WWTP (Spain). This digestate was obtained from the anaerobic digestion of mixed sludge 
and on-site centrifuged prior to use to eliminate suspended solids. The concentration of $\mathrm{NH}_{3}$ in $\mathrm{SD}$ and $\mathrm{RD}$ averaged $605.8 \pm 0.1$ and $678.9 \pm 0.6 \mathrm{ppm}$, respectively, while pHs averaged $7.57 \pm 0.05$ and $8.99 \pm 0.08$, respectively.

\subsection{Experimental Setup}

A schematic representation of the experimental setup used for ammonia recovery from digestates is shown in Figure 1. The target digestate (SD or RD) was continuously circulated using a peristaltic pump (Watson-Marlow Sci-Q 323, Spirax-Sarco Engineering plc, Cheltenham, England, UK) over the active layer of the membrane in a customized cell module [35]. A sulfuric acid solution was recirculated using a similar peristaltic pump on the support layer of the membrane. Both digestate and sulfuric acid solutions were maintained at $35^{\circ} \mathrm{C}$ in a thermostatic bath (HAAKE type E12, Thermo Fisher Scientific, Waltham, MA, USA) in 0.5 L enclosed Erlenmeyer bottles.

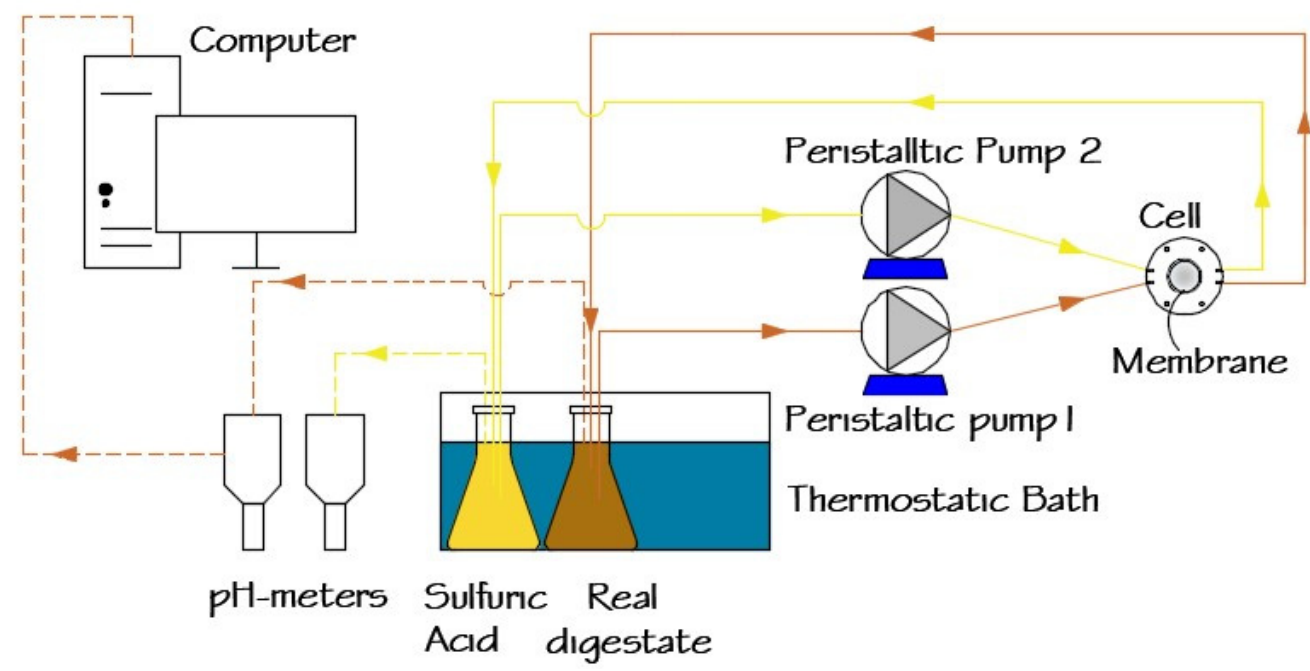

Figure 1. Schematic representation of the lab scale ammonia recovery system.

The membranes used and their main characteristics are shown in Table 1. Polytetrafluoroethylene (PTFE) and polyvinylidene difluoride (PVDF) were selected as model commercial membranes based on their ideal properties for the separation of light molecules from water in a gaseous phase.

Table 1. Description of the flat sheet membranes studied.

\begin{tabular}{cccccccc}
\hline Membrane & Material & Pore Size & $\begin{array}{c}\text { Nominal } \\
\text { Thickness }(\boldsymbol{\mu m})\end{array}$ & Contact Angle $(\boldsymbol{\theta )})$ & $\begin{array}{c}\text { Porosity } \\
(\mathbf{\%})\end{array}$ & Wettability & Manufacturer \\
\hline PVDF-100 & PVDF & $100 \mathrm{kDa}$ & 160 & $130-135$ & $*$ & hydrophobic & KOCH \\
PVDF-0.10 & PVDF & $0.10 \mu \mathrm{m}$ & 130 & $130-135$ & $*$ & hydrophobic & Sterlitech \\
PTFE-0.20 & PTFE & $0.20 \mu \mathrm{m}$ & 139 & 142 & $*$ & hydrophobic & Pall Gelman \\
PTFE-0.22 & PTFE & $0.22 \mu \mathrm{m}$ & 175 & 150 & 70 & hydrophobic & Millipore \\
PTFE-0.45 & PTFE & $0.45 \mu \mathrm{m}$ & 135 & 155 & $*$ & hydrophobic & Pall Gelman \\
\hline
\end{tabular}

* Information not supplied by manufacturers.

\subsection{Operational Conditions and Process Evaluation}

An initial test series was carried out with all the membranes initially selected (Table 1) using synthetic digestate at two different $\mathrm{pHs}$ (7.6 and 10) and two sulfuric acid concentrations $(0.005$ and $1 \mathrm{M})$ at $35^{\circ} \mathrm{C}$ with recirculation flow rates of $0.030 \mathrm{~m}^{3} \mathrm{~h}^{-1}$. Trials were carried out with intermediate sulfuric acid concentration, but with no relevance in the results. A second series of experiments was conducted with PTFE- 0.22 and real digestate at pHs of 8.9 and 10 using recirculation flow rates of $0.030 \mathrm{~m}^{3} \mathrm{~h}^{-1}$ and a sulfuric acid concentration of $1 \mathrm{M}$. Finally, a third series of experiments was carried out with both RD 
and SD and the PTFE-0.22 membrane, at a $\mathrm{pH}$ of 10 , with a sulfuric acid concentration of $1 \mathrm{M}$ and recirculation flow rates of $0.007,0.015,0.030$ and $0.045 \mathrm{~m}^{3} \mathrm{~h}^{-1}$. The membrane system was washed twice for $1 \mathrm{~h}$ after each experiment with distilled water when using SD, and with tap water (which contains sodium hypochlorite) when using RD. Samples of the digestate solution were drawn every 30 min over $3.5 \mathrm{~h}$ to analyse the concentration of $\mathrm{NH}_{3}$ and obtain $\mathrm{pH}$ values. Finally, a systematic evaluation of membrane fouling was performed by determining the pore size distribution of PTFE-0.22 membranes after their use with SD and RD, at a pH of 10 and with a sulfuric acid concentration of $1 \mathrm{M}$ at different recirculation flow rates $\left(0.007,0.015,0.030\right.$ and $\left.0.045 \mathrm{~m}^{3} \mathrm{~h}^{-1}\right)$. All experiments were carried out in duplicate.

\subsection{Analytical Methods}

The values of $\mathrm{pH}$ and temperature were monitored using a HI5522 $\mathrm{pH}$ meter Hanna Instruments (Woonsocket, RI, USA) and a Basic 20 pH meter (Crison Instruments, S.A., Alella, Barcelona, Spain) in the liquids on both sides of the membrane. $\mathrm{NH}_{3}$ was measured using the Nessler analytical method in a Shimadzu UV-160 A spectrophotometer at $425 \mathrm{~nm}$ (Shimadzu, Kyoto, Japan).

\subsection{Membrane Characterization Techniques}

Surface morphology was analysed by using Atomic Force Microscopy. Images were obtained with a Nanoscope IIIA microscope (Digital Instruments, Veeco Metrology Group, Chadds Ford, PA, USA) using the Tapping mode. Pore size distribution was analysed by the extended bubble point method, or Air Displacement Porometry (ADP), using a Coulter ${ }^{\circledR}$ Porometer-II manufactured by Coulter Electronics (Porometer, Aptco Invest, Dulles, VA, USA) [36]. Samples were first wetted with an electronic liquid FC-43 (Fluorinert ${ }^{\mathrm{TM}}, 3 \mathrm{M}$, St. Paul, MN, USA) of low surface tension $\left(\gamma 1.6 \times 10^{-2} \mathrm{~N} \mathrm{~m}^{-1}\right)$, low vapour pressure (192 Pa) and low reactivity, that can be assumed to fill all the pores given a zero contact-angle with the membrane material. The wetted sample was subjected to increasing pressure, applied by a compressed clean and dry air source. The pressure range for PTFE 0.22 membrane was $0.09-0.60 \mu \mathrm{m}$.

\subsection{Theoretical Methods}

The overall mass transfer coefficient of $\mathrm{NH}_{3}$ was calculated with Equation (2). according to [21].

$$
\frac{1}{k_{o v}}=\frac{1}{k_{s}}+\frac{1}{k_{m}}
$$

where $k_{s}$ and $k_{m}$ are the mass transfer coefficients in the digestate side and within pores, respectively. The resistance on the acid solution side can be considered negligible (i.e., mass transfer coefficient on the acid side is much larger than $k_{s}$ and $k_{m}$ ). In this context, the mass transfer coefficient on the digestate side can be estimated using Equation (3):

$$
k_{s}=\frac{D_{A W} S h}{D_{H}}
$$

where $D_{A W}$, Sh and $D_{H}$ are: diffusion coefficient of $\mathrm{NH}_{3}$ in water (calculated using the software ASPEN (AspenTech, Bedford, MA, USA) at $35^{\circ} \mathrm{C}$ ), the Sherwood dimensionless number [37], and the hydraulic diameter, respectively. Similarly, the mass transfer coefficient within pores can be calculated by Equation (4) [26,38]:

$$
k_{s}=\frac{\epsilon D_{i j}}{\tau \delta}
$$


where $\tau, \delta, D_{i j}$ and $\epsilon$ are: the tortuosity, the wall thickness of the membrane, the diffusion coefficient of $\mathrm{NH}_{3}$ in the air gap within pores, and the porosity of the membrane, respectively. Accepting Knudsen regime [21]:

$$
D_{i j}=\frac{d_{p}}{3} \sqrt{\frac{8 R T}{\pi m}}
$$

in terms of the pore diameter and $\mathrm{NH}_{3}$ molar mass $\mathrm{m}$.

The molar theoretical flux of $\mathrm{NH}_{3}$ across the membrane can be estimated using Equation (6) [39]:

$$
J_{T}=k_{o v} \Delta C
$$

here, $\Delta C$ is the difference in $\mathrm{NH}_{3}$ concentrations between the feed and permeate sides. Finally, $\mathrm{NH}_{3}$ recovery seems to follow first-order kinetics, which can be estimated using Equation (7) [40,41]:

$$
\ln \frac{C_{0}}{C_{t}}=k_{o v} \frac{A_{m}}{V_{t}} t
$$

where $k_{o v}, A_{m} / V_{t}$ and $t$ are the overall mass transfer coefficient, the effective ratio of membrane area to feed volume of the digestate, and the elapsed time, respectively. $C_{0}$ and $C_{t}$ are the concentration of ammonia at time zero and time $t$ in the digestate, respectively. $\mathrm{NH}_{3}$ recovery $(R)$ ranges between 0 and 1 (Equation (8)):

$$
R=1-\frac{C_{t}}{C_{0}}=1-e^{-k_{o v} \frac{A m}{V_{t}} t} \equiv 1-e^{-\alpha t}
$$

here $\alpha=k_{o v} \frac{A_{m}}{V_{t}}$ is the rate of concentration decrease and recovery increase. Therefore, the time needed to reach a given $R$ can be estimated using Equation (9):

$$
t(R)=-\frac{\ln (1-R)}{k_{o v} \frac{A_{m}}{V_{t}}}=-\frac{\ln (1-R)}{\alpha}
$$

\section{Results and Discussion}

\subsection{Influence of Membrane Material, $\mathrm{pH}$ and $\mathrm{H}_{2} \mathrm{SO}_{4}$ Concentration}

Five flat sheet membranes (Table 1) were investigated at a recirculation flow rate of $0.030 \mathrm{~m}^{3} \mathrm{~h}^{-1}$, a pH of 10 and a concentration of $\mathrm{H}_{2} \mathrm{SO}_{4}$ of $1 \mathrm{M}$, to elucidate the optimum material, pore size and wettability for $\mathrm{NH}_{3}$ recovery from a synthetic digestate. PTFE membranes exhibited a superior performance to PVDF membranes in terms of $\mathrm{NH}_{3}$ recovery at a $\mathrm{pH}$ of 10 (Figure 2). In this case, the highest $\mathrm{NH}_{3}$ removal recovery after $3.5 \mathrm{~h}$ $(77.7 \% \pm 0.4 \%)$ was provided by PTFE-0.22. This removal efficiency was 3.6-fold higher than those obtained for the two PVDF membranes tested. As shown in Table 1, PTFE-0.22 has a contact angle $(\theta)$ of 150 degrees [42], which corresponds to a rather hydrophobic surface [43]. In fact, a membrane with $\theta>140^{\circ}$ could be considered super-hydrophobic according to Tylkowski et al. [43]. The superior performance of the PTFE-0.22 membrane could be also explained by its asymmetric structure, as membranes with symmetric structures, with similar thickness, have been consistently shown to be less permeable [20]. Therefore, the following experiments were also conducted using PTFE-0.22 membranes. 


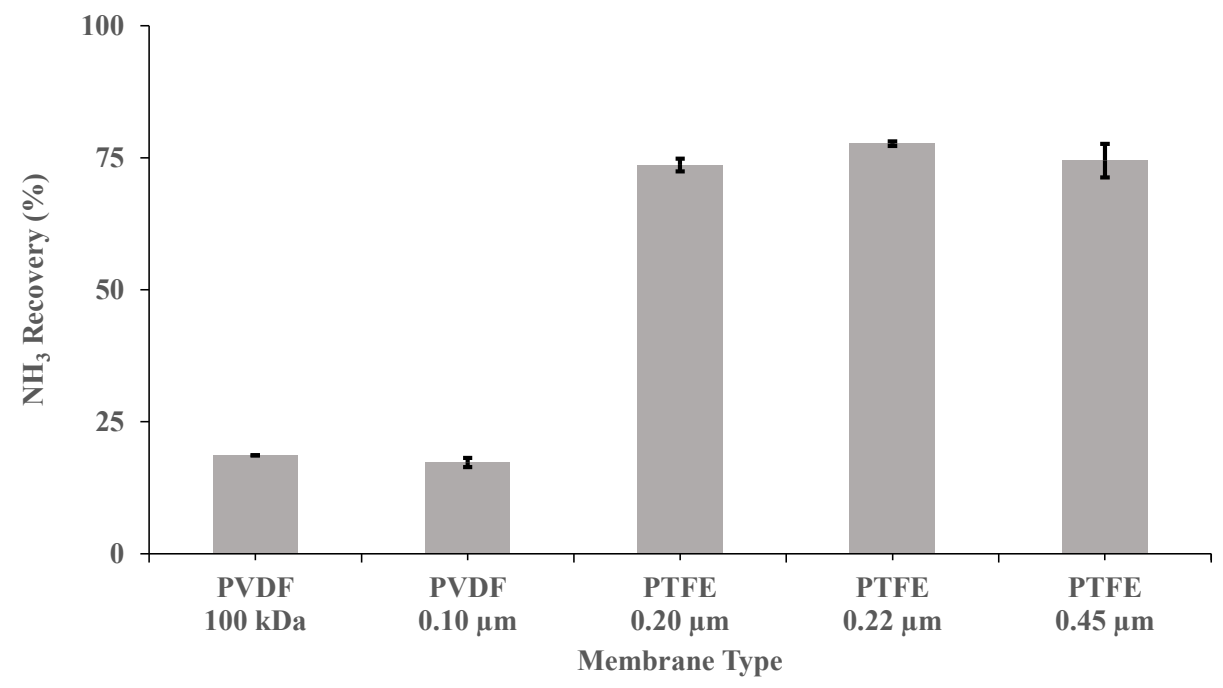

Figure 2. Influence of the type of membrane on ammonia recovery, after $3.5 \mathrm{~h}$, in SD with a recirculation flow rate of $0.030 \mathrm{~m}^{3} \mathrm{~h}^{-1}$, a $\mathrm{pH}$ of 10 and a concentration of $\mathrm{H}_{2} \mathrm{SO}_{4}$ of $1 \mathrm{M}$. Vertical bars represent the standard deviation obtained from duplicate measurements.

The influence of the digestate $\mathrm{pH}$ was also studied. This parameter determines $\mathrm{NH}_{3}$ mass transfer as it shifts the equilibrium $\mathrm{NH}_{4}^{+} \leftrightarrow \mathrm{NH}_{3}+\mathrm{H}^{+}$. In our study, higher ammonia recoveries were achieved by increasing the $\mathrm{pH}$ of the synthetic digestate because of the increase in the $\mathrm{NH}_{3}$ concentration gradient (Figure $\mathrm{S} 1$ in the Supplementary material). Nevertheless, an increase in the $\mathrm{pH}$ of the digestate above 10 does not entail large improvement in the ammonia removal [20]. Operating the process at a $\mathrm{pH}$ of 11 with a PTFE-0.22 membrane, a recirculation flow rate of $0.030 \mathrm{~m}^{3} \mathrm{~h}^{-1}$ and a concentration of $\mathrm{H}_{2} \mathrm{SO}_{4}$ of $1 \mathrm{M}$, resulted in a $\mathrm{NH}_{3}$ recovery of $82.8 \% \pm 0.4 \%$, only $10 \%$ higher than the recoveries recorded at a $\mathrm{pH}$ of $10 . \mathrm{NH}_{3}$ recovery was lower in real digestate than in synthetic digestate using a PTFE- 0.22 membrane at $\mathrm{pHs}$ of 10 and 7.6, the latter $\mathrm{pH}$ supporting lower $\mathrm{NH}_{3}$ recoveries (Figure S1 in the Supplementary material). Thus, the times needed to reach $95 \% \mathrm{NH}_{3}$ recovery significantly increased by a factor of 6.5 and 2.3 in SD and RD, respectively, when digestate $\mathrm{pH}$ was increased from 7.6 to 10 (Table 2).

Table 2. Time needed to reach $95 \% \mathrm{NH}_{3}$ recovery for the PTFE- 0.22 membrane operated with a concentration of $\mathrm{H}_{2} \mathrm{SO}_{4}$ of $1 \mathrm{M}$ and a flow rate of $0.030 \mathrm{~m}^{3} \mathrm{~h}^{-1}$.

\begin{tabular}{cccc}
\hline & \multicolumn{3}{c}{ Digestate } \\
\cline { 2 - 4 } & SD & RD \\
\hline $\mathbf{p H}$ & & $\boldsymbol{t}(\mathbf{9 5 \%}) / \mathbf{h}$ \\
\hline 7.6 & 36.03 & & 16.88 \\
10 & 5.49 & & 7.31 \\
\hline
\end{tabular}

$\mathrm{H}_{2} \mathrm{SO}_{4}$ concentration was identified, also, as a key operational parameter for $\mathrm{NH}_{3}$ recovery. The performance of a PTFE- 0.22 membrane at two concentrations of $\mathrm{H}_{2} \mathrm{SO}_{4}$ $(0.005$ and $1 \mathrm{M})$ was studied at pHs of 7.6 and 10 , under a flow rate of $0.030 \mathrm{~m}^{3} \mathrm{~h}^{-1}$ using synthetic digestate. Acid concentrations of $0.005 \mathrm{M}$ resulted in $\mathrm{NH}_{3}$ recoveries of $12.2 \% \pm 0.2 \%$ and $55.5 \% \pm 0.1 \%$ at a $\mathrm{pH}$ of 7.6 and 10 , respectively, after $3.5 \mathrm{~h}$ of operation at the same flow rate. Similarly, under the same conditions, $\mathrm{NH}_{3}$ recoveries of $22.9 \% \pm 0.4 \%$ and $77.7 \% \pm 0.4 \%$ were achieved using $\mathrm{H}_{2} \mathrm{SO}_{4}$ concentrations of $1 \mathrm{M}$ (Figure 3). Therefore, it was concluded that the best operating conditions correspond to a $\mathrm{pH}$ of 10 and $\mathrm{H}_{2} \mathrm{SO}_{4}$ concentrations of $1 \mathrm{M}$. 


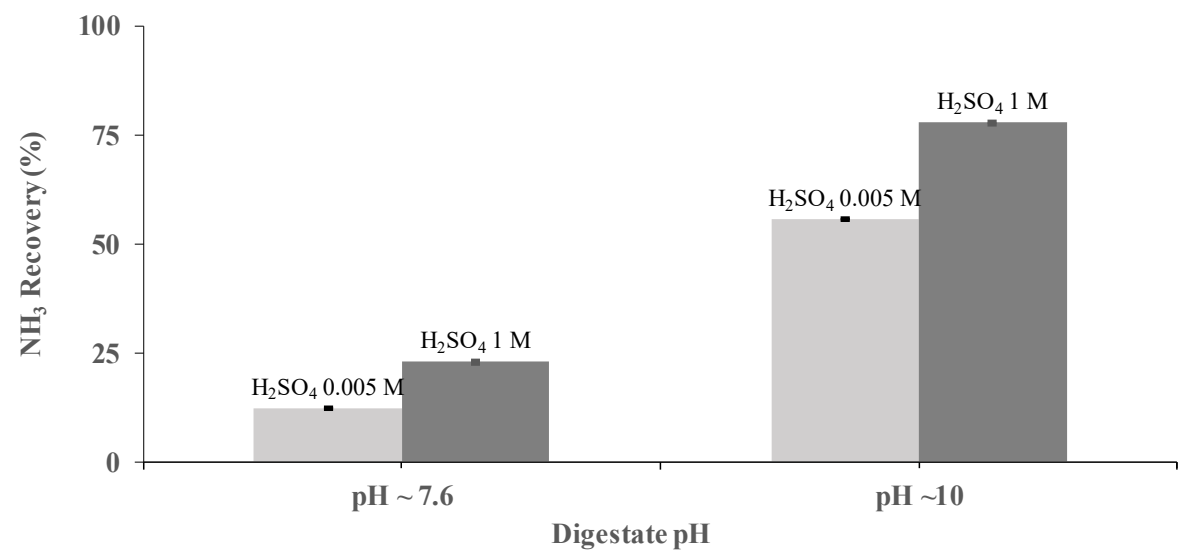

Figure 3. Influence of the sulfuric acid concentration on $\mathrm{NH}_{3}$ recovery from $\mathrm{SD}$ at $\mathrm{pHs}$ of 7.6 and 10 and a flow rate of $0.030 \mathrm{~m}^{3} \mathrm{~h}^{-1}$ using the PTFE- 0.22 membrane. Vertical bars (very short here) represent the standard deviation from replicate measurements.

\subsection{Influence of the Digestate Recirculation Flow Rate}

Ammonia removal efficiencies of $84.6 \% \pm 1.0 \%$ were achieved using the PTFE- 0.22 membrane after $3.5 \mathrm{~h}$ of experiment in synthetic digestate, which were higher than the removal efficiencies in real digestate $(71.6 \% \pm 0.3 \%)$, at $0.045 \mathrm{~m}^{3} \mathrm{~h}^{-1}$ and a $\mathrm{pH}$ of 10 . The lower $\mathrm{NH}_{3}$ recoveries in real digestate were likely due to membrane fouling. This fouling affected the $\mathrm{NH}_{3}$ permeate flux mainly due to adsorption of colloids, or solutes including ammonia, within the membrane pores, with a subsequent reduction in mean pore sizes. According to Meng et al. [44], membrane fouling typically causes cake layer formation, deposition of sludge flocs and their deposition on the membrane. The influence of the velocity of the acid solution was not herein assessed as previous literature has consistently shown that the velocity of the acid solutions does not impact significantly on $\mathrm{NH}_{3}$ mass transfer $[20,31]$.

The increase in the digestate recirculation flow rate brought about a rise in the pace of the $\mathrm{NH}_{3}$ recovery across the PTFE- 0.22 membrane regardless of the type of digestate (real or synthetic). Figure S2a,b (in Supplementary Material) show the exponential decrease of the ammonia concentration, which resulted in a rapid increase of $\mathrm{NH}_{3}$ recovery (Equation (7)). In Figure $4 a$, the corresponding rate of concentration decrease and recovery increase $\alpha$, is shown as a function of the recirculation flow rate of $\mathrm{SD}$ and $\mathrm{RD}$ (Equation (8)). The value of $\alpha$ was higher for the synthetic digestate, while the increase in digestate recirculation flow rate was positively correlated with $\mathrm{NH}_{3}$ recovery rate regardless of the type of digestate. Figure $4 \mathrm{~b}$ shows the evolution of the time needed to reach $95 \%$ recovery (Equation (9)). This time is higher for the real digestate than for the synthetic one. It is worth noting that an increase of the recirculation flow of the digestate from 0.007 to $0.045 \mathrm{~m}^{3} \mathrm{~h}^{-1}$ brought about a substantial decrease of the time needed to reach $95 \%$ recovery of $\mathrm{NH}_{3}$. In all cases, a pH of 10 was maintained. The duration of the experiment conducted at a liquid recirculation rate of $0.03 \mathrm{~m}^{3} \mathrm{~h}^{-1}$ was extended to $6 \mathrm{~h}$, in order to check how a longer time improved recovery. This experiment resulted in a final $\mathrm{NH}_{3}$ recovery of $94.3 \% \pm 0.3 \%$ in synthetic digestate in accordance with Figure $4 \mathrm{~b}$. Therefore, we concluded that over long time intervals, the evolution of recovery follows the pace assumed here. 

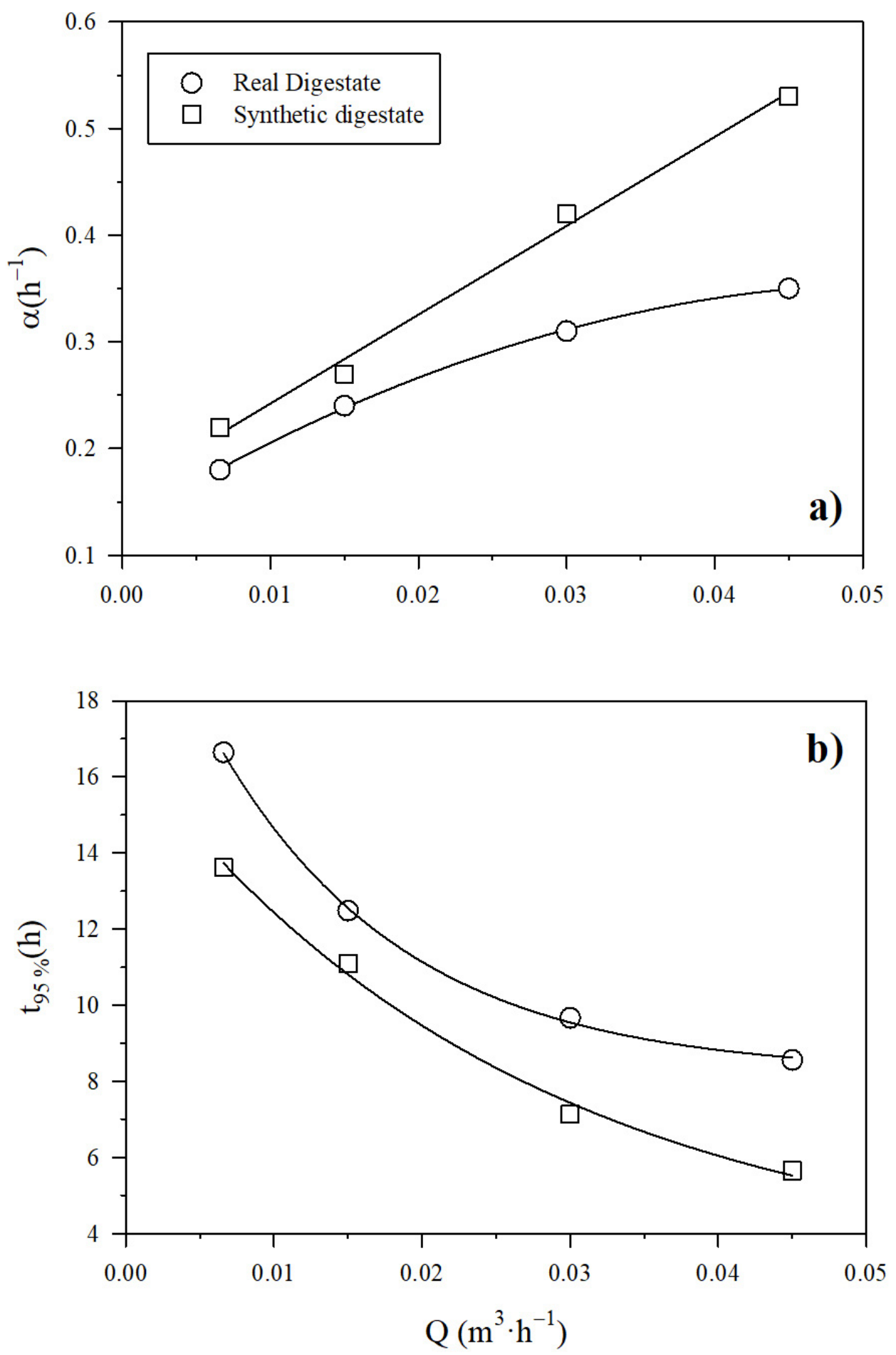

Figure 4. Influence of the recirculation flow rate on (a) $\alpha$, and (b) the time to reach $95 \% \mathrm{NH}_{3}$ recovery using a PTFE-0.22 membrane at different recirculation flow rates at a $\mathrm{pH}$ of 10 and a concentration of $\mathrm{H}_{2} \mathrm{SO}_{4}$ of $1 \mathrm{M}$ for both digestates.

The $\mathrm{NH}_{3}$ fluxes across the PTFE-0.22 membrane in both SD and RD are shown in Figure 5. They decreased as the recirculation flow rate increased because of fouling, probably induced by shear. In addition, $\mathrm{NH}_{3}$ fluxes were slightly higher in $\mathrm{SD}$ than in RD according to its lower induction of membrane fouling. By fitting theoretical to experimental fluxes and using Equations (2)-(6), the corresponding effective pore diameters 
were evaluated at the end of each experiment, as a function of the recirculation flow $Q$, which was $0.25 \mu \mathrm{m}$.

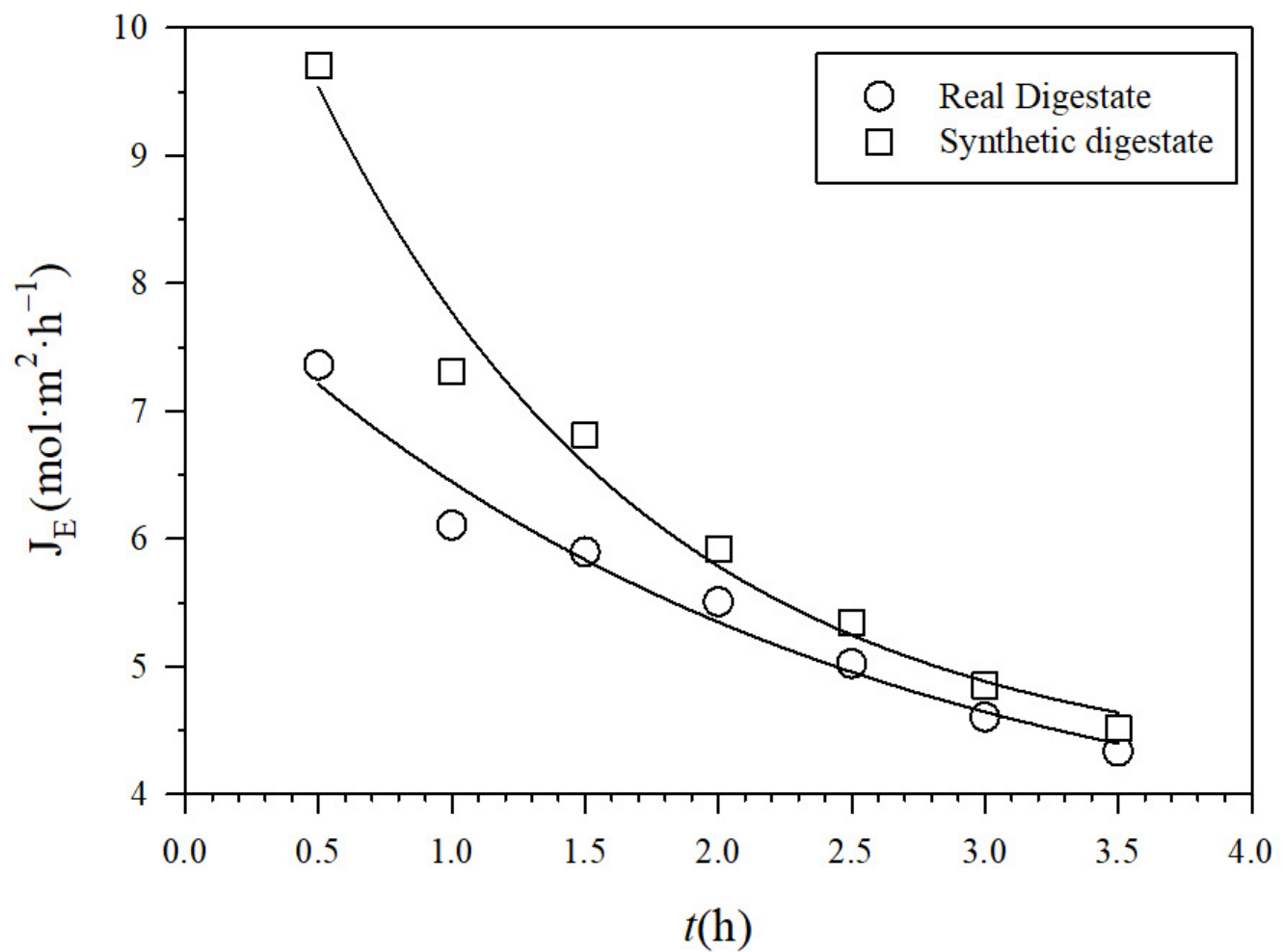

Figure 5. Experimental molar fluxes $\mathrm{J}_{\mathrm{E}}$ for recirculation rate $0.030 \mathrm{~m}^{3} \mathrm{~h}^{-1}$ for PTFE- 0.22 at a $\mathrm{pH}$ of 10 and $1 \mathrm{M} \mathrm{H}_{2} \mathrm{SO}_{4}$.

The experimental $\mathrm{NH}_{3}$ fluxes herein obtained with flat plate membranes were comparable to, but clearly higher than, those reported in the literature when using similar $\mathrm{pHs}$ with hollow fibre or tubular membranes (Table 3).

Table 3. Summary of fluxes using hydrophobic membranes.

\begin{tabular}{|c|c|c|c|c|c|c|c|}
\hline Matrix & $\begin{array}{c}C_{0} \\
(\mathrm{ppm})\end{array}$ & $\mathrm{pH}$ & $\begin{array}{c}T \\
\left({ }^{\circ} \mathrm{C}\right)\end{array}$ & $\begin{array}{c}\mathrm{H}_{2} \mathrm{SO}_{4} \\
\left(\mathrm{~mol} \mathrm{~L}^{-1}\right)\end{array}$ & $\underset{\left(\mathrm{mol} \mathrm{m}^{-2} \mathrm{~h}^{-1}\right)}{\operatorname{Flux}}$ & Membrane Configuration & Reference \\
\hline $\begin{array}{c}\text { Water } \\
\text { containing } \\
\mathrm{NH}_{3}\end{array}$ & 400 & $9-10$ & 40 & 0.3 & 0.11 & Hollow fibre (PP) & {$[21]$} \\
\hline $\begin{array}{c}\text { Simulated } \\
\text { wastewater }\end{array}$ & 120 & 10 & 25 & - & 0.18 & Hollow fibre (PVDF) & {$[20]$} \\
\hline $\begin{array}{l}\text { Digested } \\
\text { effluents }\end{array}$ & 1554 & 8 & 25 & 1 & 0.06 & Hollow fibre (PP) & [45] \\
\hline $\begin{array}{l}\text { Raw swine } \\
\text { manure }\end{array}$ & 2390 & 9 & 25 & 1 & 0.33 & Tubular (PE) & [46] \\
\hline $\begin{array}{l}\text { Landfill } \\
\text { leachate }\end{array}$ & 1300 & 10 & 25 & 0.1 & 1.27 & Hollow fibre (PP) & [37] \\
\hline $\begin{array}{l}\text { Synthetic } \\
\text { Digestate }\end{array}$ & 679 & 10 & 35 & 1 & 4.52 & Flat sheet (PTFE) & This work \\
\hline
\end{tabular}

In contrast, the overall mass transfer coefficient increased at increasing digestate recirculation flow rates. An analysis of the relative importance of the membrane mass transfer coefficient $k_{m}$, and that on the digestate side $k_{s}$, compared to the overall mass transfer coefficient $k_{o v}$, show that the largest restriction to mass transfer occurred on the 
digestate side of the membrane, while through the pores, there was a very high $\mathrm{NH}_{3}$ mass transfer. $\mathrm{NH}_{3}$ mass transfer through the pores decreased steeply when the recirculation flow rate was increased, but with a concomitant increase of the mass transfer on the digestate side of the membrane. Values of Table 4 correspond to synthetic digestate.

Table 4. Calculated mass transfer coefficients for synthetic digestate.

\begin{tabular}{|c|c|c|c|}
\hline Recirculation Rate $\left(\mathrm{m}^{3} \mathrm{~h}^{-1}\right)$ & $\begin{array}{c}k_{o v}{ }^{a} \\
\left(\mathrm{~m} \mathrm{~h}^{-1}\right)\end{array}$ & $\begin{array}{l}k_{s} \mathrm{~b} / k_{o v} \\
\left(\mathrm{~m} \mathrm{~h}^{-1}\right)\end{array}$ & $\begin{array}{l}k_{m} \mathrm{c} / k_{o v} \\
\left(\mathrm{~m} \mathrm{~h}^{-1}\right)\end{array}$ \\
\hline 0.007 & 0.13 & 3.48 & 1.40 \\
\hline 0.015 & 0.15 & 5.91 & 1.20 \\
\hline 0.030 & 0.16 & 9.73 & 1.11 \\
\hline 0.045 & 0.17 & 13.23 & 1.08 \\
\hline
\end{tabular}

\subsection{Pore Size}

The characteristics of the PTFE- 0.22 membrane were studied by air displacement porometry after the operation of the process under different experimental conditions ( $\mathrm{pH}$ of 10 , concentration of $\mathrm{H}_{2} \mathrm{SO}_{4} 1 \mathrm{M}$, recirculation flow rates $0.007,0.015,0.030$ and $0.045 \mathrm{~m}^{3} \mathrm{~h}^{-1}$ ) using both synthetic digestate and real digestate. The increase in membrane fouling reduced the pore diameter, as a result of deposits that partially or totally blocked the membrane pores (Table 5) [47]. A higher reduction in pore diameter was observed when the PTFE-0.22 membrane was exposed to longer periods of filtration, lower recirculation rates and real digestate from Valladolid WWTP. Interestingly, the mean pore size was similar in the new membrane and in the membranes used twice with recirculation flow rates of $0.045 \mathrm{~m}^{3} \mathrm{~h}^{-1}(0.3548 \mu \mathrm{m} \pm 0.0004$ and $0.3521 \mu \mathrm{m} \pm 0.0004$, respectively). This behaviour is in accordance with more specific fouling studies for PTFE in literature $[48,49]$.

Table 5. Mean pore sizes of the PTFE-0.22 membrane under different operational conditions.

\begin{tabular}{cccc}
\hline Type of Digestate & $\begin{array}{c}\text { Recirculation Rate } \\
\left(\mathbf{m}^{\mathbf{3}} \mathbf{h}^{-\mathbf{1}} \mathbf{)}\right.\end{array}$ & Type of Membrane & $\begin{array}{c}\text { Mean Pore Size } \\
(\boldsymbol{\mu} \mathbf{m})\end{array}$ \\
\hline None & None & New membrane & $0.3548 \pm 0.0004$ \\
SD & 0.045 & Used twice & $0.3521 \pm 0.0004$ \\
SD & $0.007,0.015,0.030$ & Used multiple times & $0.3443 \pm 0.0004$ \\
RD & 0.045 & Used twice & $0.3347 \pm 0.0003$ \\
RD & $0.007,0.015,0.030$ & Used multiple times & $0.3228 \pm 0.0002$ \\
\hline
\end{tabular}

\subsection{Membrane Morphology Analysis}

Figure 6a shows three-dimensional AFM pictures of PTFE-0.22 membranes that were unused or used under multiple operational conditions. More fouling was detected on the surfaces of the membrane operated with real digestate at three recirculation flow rates. The membranes operated with real digestate at the highest circulation flow rate presented a surface fouling level in agreement with the pore size results (Table 4). The unused membrane has a topography with higher roughness than for the used membranes, in accordance with Zhang et al. [50]. 

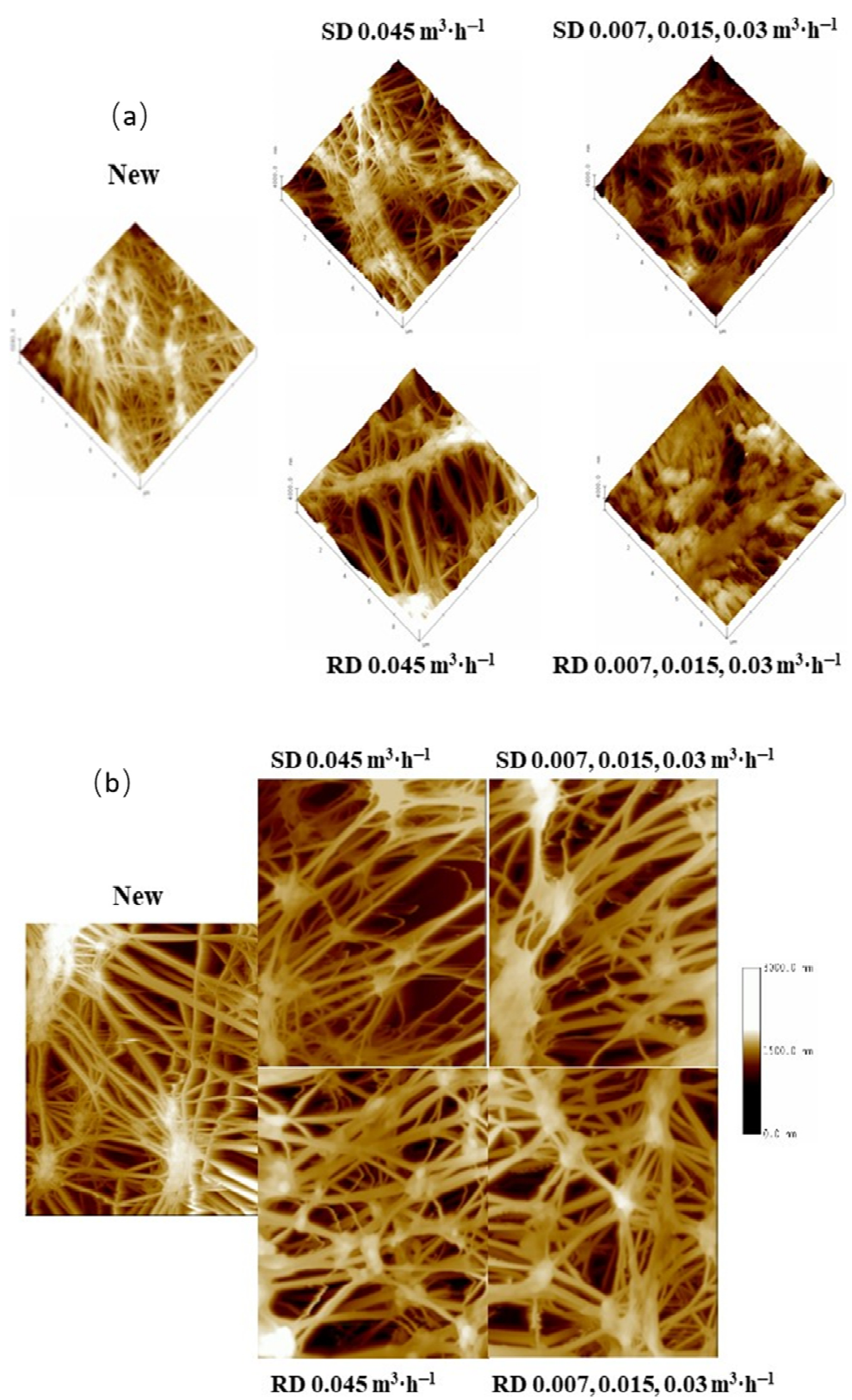

Figure 6. AFM 3D topographic images of the active layer (a) and 2D topographic images of the support layer (b) for the PTFE $0.22 \mu \mathrm{m}$ membrane under different conditions (scanned area $10 \mu \mathrm{m} \times 10 \mu \mathrm{m})$. Legends correspond to the digestate, SD or RD, treated and the recirculation flow rates used successively.

In addition, the AFM topographic images of the support layer had a very similar appearance in all membranes tested, which suggested that the use of $\mathrm{H}_{2} \mathrm{SO}_{4}$ solutions did not significantly deteriorate the membrane surface (Figure 6b).

In addition, phase contrast images were obtained to detect the presence of materials coating the membrane surface (Figure S3 in Supplementary Material). The deeper brown tones detected in the membrane, used with real digestate and at three recirculation flow rates, would correspond to organic matter from the real digestate. Fouling was not significant in the rest of the samples and the coating effect was more homogeneous. 


\section{Conclusions}

The feasibility of several commercial flat sheet membranes for ammonia recovery and their fouling were studied using synthetic and real digestate. PTFE was identified as the most efficient material for $\mathrm{NH}_{3}$ recovery regardless of the type of digestate. The highest $\mathrm{NH}_{3}$ recovery was obtained when the $\mathrm{pH}$ of the digestate was increased to 10 and $1 \mathrm{M}$ sulfuric acid was used. $\mathrm{NH}_{3}$ recovery also increased at higher digestate circulation flow rates because of the inherent reduction in mass transfer resistance. $\mathrm{NH}_{3}$ recovery was shown to follow first order kinetics and to be faster under alkaline $\mathrm{pH}$, high $\mathrm{H}_{2} \mathrm{SO}_{4}$ concentration and high recirculation flow rate on the digestate side of the membrane. A PTFE- 0.22 membrane operated under optimal conditions supported $\mathrm{NH}_{3}$ recoveries of $71.6 \% \pm 0.3 \%$ and $84.6 \% \pm 1.0 \%$ after only $3.5 \mathrm{~h}$ using real and synthetic digestates, respectively. After $6 \mathrm{~h}$ of operation, $94.3 \% \pm 0.3 \% \mathrm{NH}_{3}$ recoveries were reached in synthetic digestate under similar operational conditions in accordance with the kinetics assumed here. Membrane fouling was relevant when using real digestate and resulted in a decrease in membrane pore diameter and growing surface deposition.

Supplementary Materials: The following are available online at https:/ /www.mdpi.com/article/10 $.3390 /$ membranes12010019/s1, Figure S1: Influence of the $\mathrm{pH}$ in (a) SD and (b) RD on the time course of $\mathrm{NH}_{3}$ concentration in the feed side of the PTFE- 0.22 membrane operated with a concentration of $\mathrm{H}_{2} \mathrm{SO}_{4}$ of $1 \mathrm{M}$ and a recirculation flow rate of $0.030 \mathrm{~m}^{3} \mathrm{~h}^{-1}$. Figure S2: Time course of ammonia recovery using a PTFE- 0.22 membrane at different recirculation flow rates, a $\mathrm{pH}$ of 10, a concentration of $\mathrm{H}_{2} \mathrm{SO}_{4}$ of $1 \mathrm{M}$ in (a) synthetic digestate and (b) real digestate. Figure S3: AFM Phase Imaging of the active layer for a PTFE 0.22 membrane under different conditions (scanned area $10 \mu \mathrm{m} \times 10 \mu \mathrm{m}$ ).

Author Contributions: Conceptualization, L.P., P.P., A.H., R.M.; methodology, P.P. and R.M.; validation, L.P., P.P., A.H., R.M.; formal analysis, L.P., P.P., A.H., R.M.; investigation, F.R.; resources, L.P. and R.M.; data curation, L.P., P.P., A.H., R.M.; writing-original draft preparation, F.R.; writing-review and editing, L.P., P.P., A.H., R.M.; visualization, L.P., P.P., A.H., R.M.; supervision, L.P., P.P., A.H., R.M.; project administration, L.P. and R.M.; funding acquisition, L.P. and R.M. All authors have read and agreed to the published version of the manuscript.

Funding: This research was funded by the Regional Government of Castilla y León and the European FEDER Program (VA088G19, CLU 2017-09 and UIC 071) and the Spanish Ministry of Science and Innovation (project: PID2019-109403RB-C21/AEI/10.13039/501100011033).

Institutional Review Board Statement: Not applicable.

Informed Consent Statement: Not applicable.

Data Availability Statement: Not applicable.

Acknowledgments: This work was supported by the Regional Government of Castilla y León and the European FEDER Program (VA088G19, CLU 2017-09 and UIC 071) and the Spanish Ministry of Science and Innovation (project: PID2019-109403RB-C21/AEI/10.13039/501100011033). F. Rivera thanks University of Valladolid for the PhD Contract.

Conflicts of Interest: The authors declare no conflict of interest.

\section{References}

1. Forster, C.F. Biotechnology and Wastewater Treatment; University of Cambridge: Cambridge, UK, 1985.

2. Tonelli, A.R.; Pham, A. Bronchiectasis, a long-term sequela of ammonia inhalation: A case report and review of the literature. Burns 2009, 35, 451-453. [CrossRef] [PubMed]

3. De La Hoz, R.E.; Schlueter, D.P.; Rom, W.N. Chronic lung disease secondary to ammonia inhalation injury: A report on three cases. Am. J. Ind. Med. 1996, 29, 209-214. [CrossRef]

4. Brautbar, N.; Wu, M.P.; Richter, E.D. Chronic ammonia inhalation and interstitial pulmonary fibrosis: A Case report and review of the literature. Arch. Environ. Health 2003, 58, 592-596. [CrossRef] [PubMed]

5. Ni, H.; Fan, X.M.; Guo, H.N.; Liang, J.H.; Li, Q.R.; Yang, L.; Li, H.; Li, H.H. Comprehensive utilization of activated sludge for the preparation of hydrolytic enzymes, polyhydroxyalkanoates, and water-retaining organic fertilizer. Prep. Biochem. Biotechnol. 2017, 47, 611-618. [CrossRef] 
6. Hermassi, M.; Valderrama, C.; Dosta, J.; Cortina, J.L.; Batis, N.H. Evaluation of hydroxyapatite crystallization in a batch reactor for the valorization of alkaline phosphate concentrates from wastewater treatment plants using calcium chloride. Chem. Eng. J. 2015, 267, 142-152. [CrossRef]

7. Sutton, P.M.; Rittmann, B.E.; Schraa, O.J.; Banaszak, J.E.; Togna, A.P. Wastewater as a resource: A unique approach to achieving energy sustainability. Water Sci. Technol. 2011, 63, 2004-2009. [CrossRef] [PubMed]

8. Licon Bernal, E.E.; Maya, C.; Valderrama, C.; Cortina, J.L. Valorization of ammonia concentrates from treated urban wastewater using liquid-liquid membrane contactors. Chem. Eng. J. 2016, 302, 641-649. [CrossRef]

9. Zheng, Y.; Wang, A. Evaluation of ammonium removal using a chitosan-g-poly (acrylic acid)/rectorite hydrogel composite. J. Hazard. Mater. 2009, 171, 671-677. [CrossRef]

10. Ozturk, I.; Altinbas, M.; Koyuncu, I.; Arikan, O.; Gomec-Yangin, C. Advanced physico-chemical treatment experiences on young municipal landfill leachates. Waste Manag. 2003, 23, 441-446. [CrossRef]

11. Hung, C.M.; Lou, J.C.; Lin, C.H. Removal of ammonia solutions used in catalytic wet oxidation processes. Chemosphere 2003, 52, 989-995. [CrossRef]

12. Jorgensen, T.C.; Weatherley, L.R. Ammonia removal from wastewater by ion exchange in the presence of organic contaminants. Water Res. 2003, 37, 1723-1728. [CrossRef]

13. Provolo, G.; Perazzolo, F.; Mattachini, G.; Finzi, A.; Naldi, E.; Riva, E. Nitrogen removal from digested slurries using a simplified ammonia stripping technique. Waste Manag. 2017, 69, 154-161. [CrossRef]

14. Wang, G.; Xu, X.; Zhou, L.; Wang, C.; Yang, F. A pilot-scale study on the start-up of partial nitrification-anammox process for anaerobic sludge digester liquor treatment. Bioresour. Technol. 2017, 241, 181-189. [CrossRef]

15. Gonzalez-Martinez, A.; Poyatos, J.M.; Hontoria, E.; Gonzalez-Lopez, J.; Osorio, F. Treatment of Effluents Polluted by Nitrogen with New Biological Technologies Based on Autotrophic Nitrification-Denitrification Processes. Recent Pat. Biotechnol. 2011, 5, 74-84. [CrossRef] [PubMed]

16. Tchobanoglous, G.; Burton, F.L. Wastewater Engineering Treatment, Disposal and Reuse; McGraw-Hill Inc.: New York, NY, USA, 1991

17. Vineyard, D.; Hicks, A.; Karthikeyan, K.G.; Barak, P. Economic analysis of electrodialysis, denitrification, and anammox for nitrogen removal in municipal wastewater treatment. J. Clean. Prod. 2020, 262, 121145. [CrossRef]

18. Rothausen, S.G.S.A.; Conway, D. Greenhouse-gas emissions from energy use in the water sector. Nat. Clim. Chang. 2011, 1, 210-219. [CrossRef]

19. Hall, M.R.; West, J.; Sherman, B.; Lane, J.; De Haas, D. Long-term trends and opportunities for managing regional water supply and wastewater greenhouse gas emissions. Environ. Sci. Technol. 2011, 45, 5434-5440. [CrossRef]

20. Tan, X.; Tan, S.P.; Teo, W.K.; Li, K. Polyvinylidene fluoride (PVDF) hollow fibre membranes for ammonia removal from water. J. Membr. Sci. 2006, 271, 59-68. [CrossRef]

21. Hasanoĝlu, A.; Romero, J.; Pérez, B.; Plaza, A. Ammonia removal from wastewater streams through membrane contactors: Experimental and theoretical analysis of operation parameters and configuration. Chem. Eng. J. 2010, 160, 530-537. [CrossRef]

22. Norddahl, B.; Horn, V.G.; Larsson, M.; du Preez, J.H.; Christensen, K. A membrane contactor for ammonia stripping, pilot scale experience and modeling. Desalination 2006, 199, 172-174. [CrossRef]

23. Brennan, B.; Briciu-Burghina, C.; Hickey, S.; Abadie, T.; Al Ma Awali, S.M.; Delaure, Y.; Durkan, J.; Holland, L.; Quilty, B.; Tajparast, M.; et al. Pilot scale study: First demonstration of hydrophobic membranes for the removal of ammonia molecules from rendering condensate wastewater. Int. J. Mol. Sci. 2020, 21, 3914. [CrossRef]

24. Yeon, S.H.; Sea, B.; Park, Y.I.; Lee, K.H. Determination of mass transfer rates in PVDF and PTFE hollow fiber membranes for $\mathrm{CO}_{2}$ absorption. Sep. Sci. Technol. 2003, 38, 271-293. [CrossRef]

25. Malek, A.; Li, K.; Teo, W.K. Modeling of Microporous Hollow Fiber Membrane Modules Operated under Partially Wetted Conditions. Ind. Eng. Chem. Res. 1997, 36, 784-793. [CrossRef]

26. Mahmud, H.; Kumar, A.; Narbaitz, R.M.; Matsuura, T. A study of mass transfer in the membrane air-stripping process using microporous polypropylene hollow fibers. J. Membr. Sci. 2000, 179, 29-41. [CrossRef]

27. Vecino, X.; Reig, M.; Bhushan, B.; Gibert, O.; Valderrama, C.; Cortina, J.L. Liquid fertilizer production by ammonia recovery from treated ammonia-rich regenerated streams using liquid-liquid membrane contactors. Chem. Eng. J. 2019, 360, 890-899. [CrossRef]

28. Sheikh, M.; Reig, M.; Vecino, X.; Lopez, J.; Rezakazemi, M.; Valderrama, C.A.; Cortina, J.L. Liquid-Liquid membrane contactors incorporating surface skin asymmetric hollow fibres of poly(4-methyl-1-pentene) for ammonium recovery as liquid fertilisers. Sep. Purif. Technol. 2022, 283, 120212. [CrossRef]

29. Vecino, X.; Reig, M.; Gibert, O.; Valderrama, C.; Cortina, J.L. Integration of liquid-liquid membrane contactors and electrodialysis for ammonium recovery and concentration as a liquid fertilizer. Chemosphere 2020, 245, 125606. [CrossRef]

30. Carter, D.; Rose, L.; Awobusuyi, T.; Gauthier, M.; Tezel, F.H.; Kruczek, B. Characterization of commercial RO membranes for the concentration of ammonia converted to ammonium sulfate from anaerobic digesters. Desalination 2015, 368, 127-134. [CrossRef]

31. Darestani, M.; Haigh, V.; Couperthwaite, S.J.; Millar, G.J.; Nghiem, L.D. Hollow fibre membrane contactors for ammonia recovery: Current status and future developments. J. Environ. Chem. Eng. 2017, 5, 1349-1359. [CrossRef]

32. Damtie, M.M.; Volpin, F.; Yao, M.; Tijing, L.D.; Hailemariam, R.H.; Bao, T.; Park, K.; Shon, H.K.; Choi, J. Ammonia recovery from human urine as liquid fertilizers in hollow fiber membrane contactor: Effects of permeate chemistry. Environ. Eng. Res. 2021, 26, 190523. [CrossRef] 
33. Li, L.; Lollar, B.S.; Li, H.; Wortmann, U.G.; Lacrampe-Couloume, G. Ammonium stability and nitrogen isotope fractionations for NH4+-NH 3(aq)-NH 3(gas) systems at $20-70{ }^{\circ} \mathrm{C}$ and $\mathrm{pH}$ of 2-13: Applications to habitability and nitrogen cycling in low-temperature hydrothermal systems. Geochim. Cosmochim. Acta 2012, 84, 280-296. [CrossRef]

34. Torres-Franco, A.F.; Zuluaga, M.; Hernández-Roldán, D.; Leroy-Freitas, D.; Sepúlveda-Muñoz, C.A.; Blanco, S.; Mota, C.R.; Muñoz, R. Assessment of the Performance of an Anoxic aerobic Microalgal-bacterial System Treating High-strength wastewater. Chemosphere 2021, 270, 129437. [CrossRef]

35. Montalvillo, M.; Silva, V.; Palacio, L.; Calvo, J.I.; Carmona, F.J.; Hernández, A.; Prádanos, P. Charge and dielectric characterization of nanofiltration membranes by impedance spectroscopy. J. Membr. Sci. 2014, 454, 163-173. [CrossRef]

36. Hernández, A.; Calvo, J.I.; Prádanos, P.; Tejerina, F. Pore size distributions in microporous membranes. A critical analysis of the bubble point extended method. J. Membr. Sci. 1996, 112, 1-12. [CrossRef]

37. Amaral, M.C.; Magalhães, N.C.; Moravia, W.G.; Ferreira, C.D. Ammonia recovery from landfill leachate using hydrophobic membrane contactors. Water Sci. Technol. 2016, 74, 2177-2184. [CrossRef] [PubMed]

38. Gabelman, A.; Hwang, S.T. Hollow fiber membrane contactors. J. Membr. Sci. 1999, 159, 61-106. [CrossRef]

39. Guo, J.; Lee, J.G.; Tan, T.; Yeo, J.; Wong, P.W.; Ghaffour, N.; An, A.K. Enhanced ammonia recovery from wastewater by Nafion membrane with highly porous honeycomb nanostructure and its mechanism in membrane distillation. J. Membr. Sci. 2019, 590, 117265. [CrossRef]

40. Zhu, Z.; Hao, Z.; Shen, Z.; Chen, J. Modified modeling of the effect of $\mathrm{pH}$ and viscosity on the mass transfer in hydrophobic hollow fiber membrane contactors. J. Membr. Sci. 2005, 250, 269-276. [CrossRef]

41. Tun, L.L.; Jeong, D.; Jeong, S.; Cho, K.; Lee, S.; Bae, H. Dewatering of source-separated human urine for nitrogen recovery by membrane distillation. J. Membr. Sci. 2016, 512, 13-20. [CrossRef]

42. Cabrerizo, M.A. Bubble and Drop Interfaces: Selected Papers from International Workshop on Bubble and Drop Interfaces; Elsevier: Amsterdam, The Netherlands, 2008.

43. Tylkowski, B.; Tsibranska, I. Overview of main techniques used for membrane characterization. J. Chem. Technol. Metall. 2015, $50,3-12$.

44. Meng, F.; Chae, S.R.; Drews, A.; Kraume, M.; Shin, H.S.; Yang, F. Recent advances in membrane bioreactors (MBRs): Membrane fouling and membrane material. Water Res. 2009, 43, 1489-1512. [CrossRef] [PubMed]

45. Dube, P.J.; Vanotti, M.B.; Szogi, A.A.; García-González, M.C. Enhancing recovery of ammonia from swine manure anaerobic digester effluent using gas-permeable membrane technology. Waste Manag. 2016, 49, 372-377. [CrossRef] [PubMed]

46. García-González, M.C.; Vanotti, M.B.; Szogi, A.A. Recovery of ammonia from swine manure using gas-permeable membranes: Effect of aeration. J. Environ. Manag. 2015, 152, 19-26. [CrossRef] [PubMed]

47. Wu, H.; Kanora, A.; Schwartz, D.K. Fouling of microfiltration membranes by bidisperse particle solutions. J. Membr. Sci. 2022, 641, 119878. [CrossRef]

48. Liu, C.; Chen, L.; Zhu, L. Fouling mechanism of hydrophobic polytetrafluoroethylene (PTFE) membrane by differently charged organics during direct contact membrane distillation (DCMD) process: An especial interest in the feed properties. J. Membr. Sci. 2018, 548, 125-135. [CrossRef]

49. Zhang, B.; Huang, D.; Shen, Y.; Yin, W.; Gao, X.; Zhang, B.; Shi, W. Treatment of alkali/surfactant/polymer flooding oilfield wastewater with polytetrafluoroethylene microfiltration membrane: Performance and membrane fouling. J. Environ. Chem. Eng. 2020, 8, 104462. [CrossRef]

50. Zhang, B.; Shi, W.; Yu, S.; Zhu, Y.; Zhang, R.; Li, L. Optimization of cleaning conditions on a polytetrafluoroethylene (PTFE) microfiltration membrane used in treatment of oil-field wastewater. RSC Adv. 2015, 5, 104960-104971. [CrossRef] 